\title{
Studies in Bacidia sensu lato (lichenized Ascomycetes: Lecanorales). II. Six new combinations in Fellhanera Vězda
}

\author{
R. LÜCKING, M. E. S. CÁCERES, K. KALB and E. SÉRUSIAUX
}

\begin{abstract}
In the framework of ongoing studies on tropical representatives of Bacidia sensu lato, six species so far included in that genus are transferred to Fellhanera: Fellhanera africana (Vèzda) Lücking comb. nov. (Bas.: Bacidia africana Vězda), Fellhanera albidocincta (Vain.) Lücking comb. nov. (Bas.: Bilimbia albidocincta Vain.), Fellhanera fragilis (Vězda) Lücking \& Kalb comb. nov. (Bas.: Bacidia fragilis Vẽzda), Fellhanera mastothallina (Vain.) Lücking \& Sérus. comb.nov. (Bas.: Bacidia mastothallina Vain.), Fellhanera naevia (Vain.) Lücking \& Cáceres comb. nov. (Bas.: Bacidia naevia Vain.), and Fellhanera submicrommata (Vězda) Lücking \& Kalb comb. nov. (Bas.: Bacidia submicrommata Vězda). Fellhanera angustispora Lücking is reduced into synonymy with $F$. naevia.
\end{abstract}

(C) 2001 The British Lichen Society

\section{Introduction}

In the typological concept of Zahlbruckner (1921-1940), Bacidia made up one of the largest genera of crustose lichens, and this applied also to foliicolous representatives (Santesson 1952). Subsequent attempts to achieve a more natural classification resulted in the transfer of many species to newly established, often non-related genera (Vězda 1986, 1991; Ekman 1996). Of the more than 60 foliicolous species accepted in Bacidia sensu lato until recently (Vězda 1980; Sérusiaux 1993), only 18 are currently retained in this genus (Lücking et al. 2000). In the course of an ongoing revision of tropical representatives of Bacidia sensu lato (Kalb et al. 2000), we realized that none of these taxa belongs to Bacidia sensu stricto as defined by Hafellner (1984) and Ekman

R. Lücking and M. E. S. Cáceres: Lehrstuhl für Pflanzensystematik, Universität Bayreuth, D-95440 Bayreuth, Germany.

K. Kalb: Lichenologisches Institut, Im Tal 12, D-92318 Neumarkt/Opf., Germany.

E. Sérusiaux: Research Associate F.N.R.S., Department of Botany, University of Liège, Sart Tilman, B-4000 Liège, Belgium.

0024-2829/01/030189+06\$35.00/0
(1996), and instead should be referred to the Pilocarpaceae. While new genera will be introduced for two distinct species groups (Lücking et al., unpubl.), six taxa can be accommodated in the genus Fellhanera as circumscribed by Lücking (1997).

\section{Fellhanera africana (Vězda) Lücking comb. nov.}

Bacidia africana Vězda, Folia Geobot. Phytotax., Praha, 10: 415 (1975); type: Tanzania, Pócs 6397 (hb. Vězda-holotype!).

\section{(Fig. 1A \& B)}

Diagnostic features. Thallus foliicolous, continuous, thin, smooth, pale greenish grey. Apothecia very rare, adnate, rounded to irregular in outline, $0.3^{\circ}-0.4 \mathrm{~mm}$ diam.; disc orange, slightly convex; margin thin, chamois-coloured. Excipulum prosoplectenchymatous. Hypothecium yellowish. Paraphyses slightly branched. Asci of the Byssoloma-type. Ascospores 3-septate, oblong, 14-16 $\times 2-3 \mu \mathrm{m}$. Conidiomata pycnidia, flask-shaped, chamois-coloured, with an up to $1 \mathrm{~mm}$ long beak; conidia simple, oblong-bacillar, c. $2 \times 1 \mu \mathrm{m}$.

(C) 2001 The British Lichen Society 

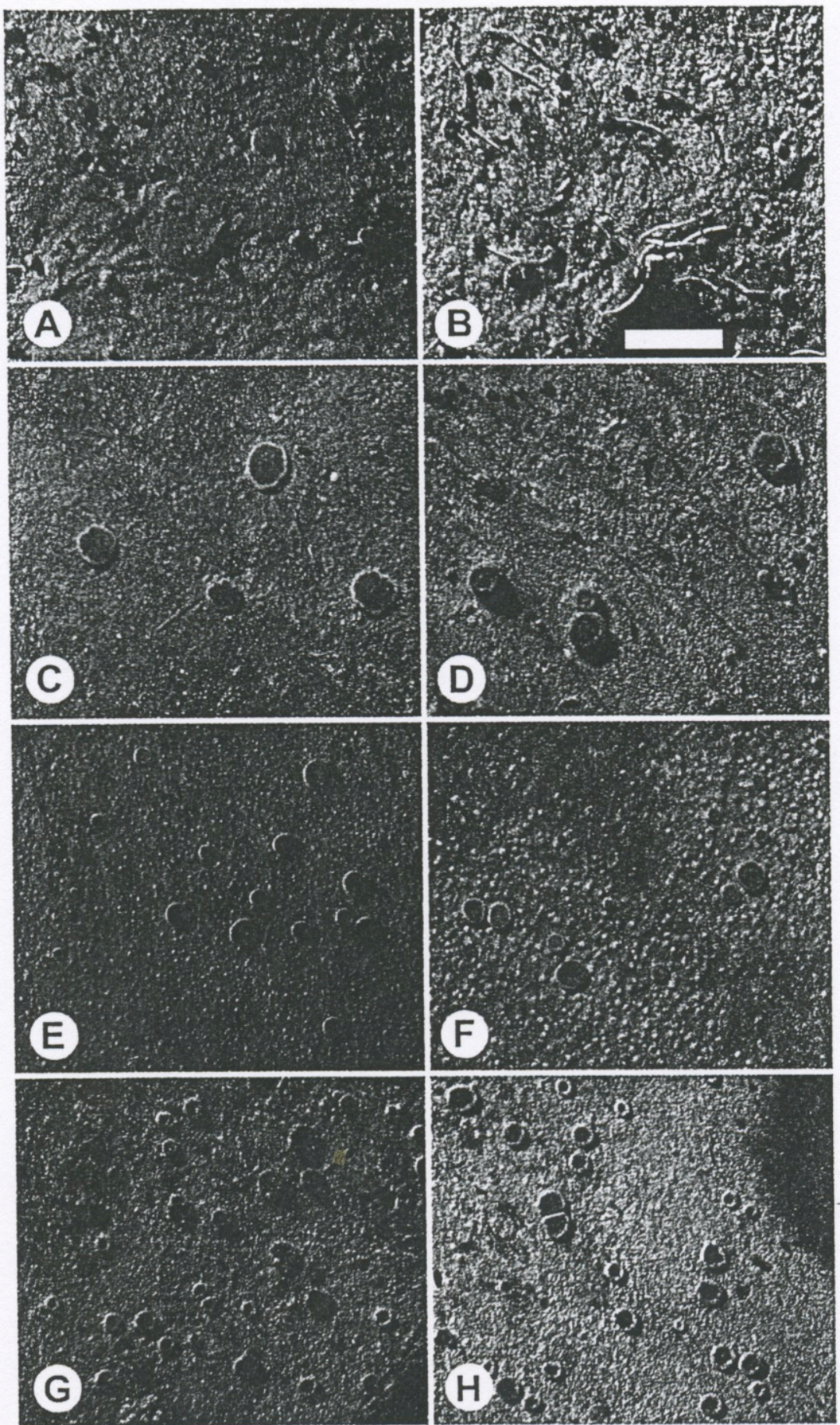

FIG. 1. Fellhanera species. A \& B, F. africana, B with pycnidia (holotype); C, F. albidocincta (holotype); D, F. fragilis (holotype); E \& F, F. mastothallina (E, Papua New Guinea; F, New Caledonia); G \& H, F. submicrommata (G, holotype; H, Guyana). Scale $=1 \mathrm{~mm}$. 
Notes. Fellhanera africana is quite an snigmatic lichen whose taxonomic affinities are difficult to establish. Externally its apothecia are similar to those of Byssoloma minutissimum Kalb \& Vězda, and its ascustype demonstrates that it does belong to the Pilocarpaceae. However, none of the genera currently accepted in this family fits perfectly. Except for the Byssoloma-like appearance, the excipular structure points to Fellhaneropsis, while the conidia are of the same type as found in Bapalmuia, Byssolecania and the Fellhanera fuscatula group Lücking 1997). Flask-shaped, beaked pycnidia are rare among foliicolous lichens but widespread in other groups of lichens; they are found in the Ostropales (e.g. Psorotheciopsis) and Gyalectales (e.g. Coenogonium), but also in the Pilocarpaceae, for example Fellhanera vandenberghenii (Sérus.) Vězda (Santesson 1952; Sérusiaux 1983; Lücking 1999). As with $F$. albidocincta (see below), we refrain from establishing a separate genus for this taxon and instead refer it to Fellhanera, which we consider the most aclusive genus in the Pilocarpaceae (Lücking 1997).

Additional specimens examined. Democratic Republic of Congo: Kivu: Irangi, INRS Reserve, $850 \mathrm{~m}$, foliicolous, 1978, Lambinon 78/262 (LG).-Papua New Guinea: Madang: Brahman Mission, S of Ramu river, lowland forest regrowth after selective logging, foliicolous, 1995, Sérusiaux 15805 (LG).

\section{Fellhanera albidocincta (Vain.) \\ Lücking comb. nov.}

Bilimbia albidocincta Vain., Ann. Acad. Sci. Fenn., ser. 1, 15: 84 (1921).-Bacidia albidocincta (Vain.) Zahlbr., atal. Lich. Univ. 4: 99 (1926); Santesson, Symb. Bot. Ups. 12: 469 (1952); type: Philippines, Robinson s.n. (TUR-Vainio 21560-holotype!).

(Fig. 1C)

Diagnostic features. Thallus foliicolous, thin, continuous to irregularly dispersed, smooth, pale greenish to brownish grey. Apothecia sessile, rounded, $0.3-0.5 \mathrm{~mm}$ diam.; disc orange-brown to brown, flat to slightly convex; margin distinct, persistent, shamois-coloured, with a finely pilose surrace. Excipulum encrusted with colourless crystals; after dissolving the crystals in $\mathrm{KOH}$, its internal parts appear paraplectenchymatous, while external parts ' are composed of short hyphae with cylindrical to slightly inflated cells. Hypothecium brownish. Paraphyses branched and anastomosing. Asci of the Byssoloma-type. Ascospores 3-septate, oblong-ellipsoid, 12-16 $\times$ 3-4 $\mu \mathrm{m}$. Conidiomata unknown.

Notes. Santesson (1952) considered Bilimbia albidocincta Vain. and B. annua Vain., both established in the same paper (Vainio 1921), to be conspecific and adopted the former epithet for a species apparently restricted to tropical Asia. Its status remained unclear until we examined the type material of Bilimbia albidocincta and B. annua, and several recent collections from tropical Africa, Asia and Australia.

Bilimbia annua is characterized by a pale bluish grey thallus and small, yellowish apothecia with a thin, compact margin with a finely byssoid surface. The exciple is encrusted with colourless crystals and, after application of $\mathrm{KOH}$, dissolves almost completely into free hyphae with cylindrical cells. This taxon is conspecific with two recently described species in the genus Byssoloma, B. dimerelloides Sipman \& Aptroot and B. clauzadei Kalb \& Vězda, and the new combination Byssoloma annuum (Vain.) Thor, Lücking \& Matsumoto has been introduced for it (Thor et al. 2000).

The type material of Bilimbia albidocincta is not very well-developed. However, other collections gave us a better understanding of the range of variation of this taxon. Bilimbia albidocincta differs from $B$. annua by the absence of a bluish tinge in the thallus, the larger apothecia with orange-brown to brown disc and thicker margin, and the internal structure of the exciple. As in the latter species, it is encrusted with crystals, but its inner parts remain paraplectenchymatous after application of $\mathrm{KOH}$, while only the outer parts consist of free hyphae. We are therefore convinced that $B$. albidocincta represents a distinct taxon. On the other hand, its generic position is uncertain. While the partly byssoid exciple 
suggests placement in Byssoloma (a similar excipular structure is known in $B$. syzygii Vězda \& Vivant), the inner paraplectenchymatous part is more typical of Fellhanera. Lücking (1997) proposed that unless sound arguments justify the establishment of separate genera, such transitional species should be referred to the phylogenetically more inclusive genus, which is believed to be Fellhanera (Lücking 1997).

Additional specimen examined. South Africa: Henssen 28248 (hb. Henssen).

\section{Fellhanera fragilis (Vězda) Lücking \& Kalb comb. nov.}

Bacidia fragilis Vẽzda, Folia Geobot. Phytotax., Praha, 10: 417 (1975); type: Tanzania, Pócs 6476 (hb. Vězda-holotype!).

\section{(Fig. 1D)}

Diagnostic features. Thallus foliicolous, continuous, smooth, pale brownish grey. Apothecia sessile, rounded, $0.5-0.6 \mathrm{~mm}$ diam.; disc dark brown, flat to very slightly convex; margin distinct, persistent, chamoiscoloured. Excipulum typically paraplectenchymatous. Hypothecium reddish brown, $\mathrm{K}+$ purplish. Paraphyses branched and anastomosing. Asci of the Byssolomatype. Ascospores (7-)11-15(-19)-septate, cylindrical, $35-55 \times 3-5 \mu \mathrm{m}$, often broken into parts. Conidiomata unknown.

Notes. The relationships between this taxon and Bacidia brasiliensis (Müll. Arg.) Zahlbr. on one hand, and the group of species eventually separated as Fellhanera on the other, were discussed by Vězda (1975a). Initially, we considered Bacidia fragilis to be more closely related to the Bacidia brasiliensis-aggregate than to Fellhanera sensu stricto. However, the comparatively broad ascospores and the branched and anastomosing paraphyses justify its inclusion in Fellhanera. Indeed, this species seems to be the extreme of a series of species with an increasing number of ascospore septa, ranging from $F$. misionensis Ferraro \& Lücking (1-septate), F. rhapidophylli (Rehm) Vězda (3-septate), F. subfuscatula Lücking (5- septate), F. fuscatula (Müll. Arg.) Vězda (7-septate), F. longispora Lücking (7-11septate), and $F$. fragilis. A particular feature of the latter species is the $\mathrm{K}+$ purplish hypothecium, which is not observed in the other species mentioned.

Additional specimen examined. Kenya: Coastal Province: Kwale District, Shimba Hills, $4^{\circ} 19^{\prime}$ S, $39^{\circ} 21^{\prime} \mathrm{E}, 300 \mathrm{~m}$, foliicolous, ix 1985, Kalb E Schrögl s.n. (hb. Kalb).

\section{Fellhanera mastothallina (Vain.) Lücking \& Sérus. comb. nov.}

Bacidia mastothallina Vain., Ann. Acad. Sci. Fenn., ser. A, 15: 64 (1921); Santesson, Symb. Bot. Ups. 12: 451 (1952).-Bacidina mastothallina (Vain.) Vèzda in Vězda et al., Ann. Naturh. Mus. Wien 99B: 738 (1997); type: Philippines, Robinson \& Ramos 11900 (TUR-holotype!).

\section{(Fig. 1E \& F)}

Diagnostic features. Thallus foliicolous, continuous, verrucose, pale greenish to brownish grey; verrucae pale brownish to orange-red, filled with ochraceous brown crystals. Apothecia sessile, rounded, 0.3$0.5 \mathrm{~mm}$ diam.; disc dark brown, flat to very slightly convex; margin thin but usually persistent, pale grey. Excipulum encrusted with colourless crystals; after dissolving the crystals in $\mathrm{KOH}$, internal parts appear paraand external parts proso-plectenchymatous. Hypothecium dark brown. Paraphyses simple to slightly branched. Asci of the Byssoloma-type. Ascospores 7-septate, cylindrical, $22-32 \times 3-4 \mu \mathrm{m}$. Conidiomata unknown.

Notes. Fellhanera mastothallina is a very characteristic species, being widespread in tropical Asia and often locally abundant. Santesson (1952) makes no statements about its relationships, and Vězda (in Vězda et al. 1997) gives no reason why he referred this taxon to Bacidina Vězda. The asci clearly belong to the Byssoloma-type, and the general appearance of the species is very much that of a genuine Fellhanera, although some anatomical features, i.e. the prosoplectenchymatous outer exciple and the almost simple paraphyses, do not completely 
coincide with typical representatives of the genus.

Selected specimens examined. Indonesia: Bali: Alas Kedadung near Kukuh, foliicolous, i 1989, Schumm s.n. (hb. Schumm).-Papua New Guinea: Madang: Balek Wildlife Reserve (near Madang), $20 \mathrm{~m}$, foliicolous, 1992, Sérusiaux 13555-49 (LG).-Australia: Queensland: Wooroonooran National Park, Josephine Falls, $17^{\circ} 26^{\prime} \mathrm{S}, 145^{\circ} 52^{\prime} \mathrm{E}, 70 \mathrm{~m}, 1998$, Streimann $\mathcal{E}$ Mischler 61652 (CANB).-New Caledonia: Sud: Monts Koghis-Dumbéa, $22^{\circ} 14^{\prime} \mathrm{S}, 166^{\circ} 30^{\prime} \mathrm{E}, 550 \mathrm{~m}$, foliicolous, viii 1994, Kalb $\mathbb{E}$ Kalb s.n. (hb. Kalb).

\section{Gellhanera naevia (Vain.) Lücking \& Cáceres comb. nov.}

Bacidia naevia Vain., Ann. Acad. Sci. Fenn., ser. A, 15: 66 (1921); type: Philippines, Robinson 18221 (TUR-holotype, not seen; F-isotype!).

Fellhanera angustispora Lücking, Trop. Bryol. 13: 143 (1997); type: Costa Rica, Lücking 91-4932 (ULM-holotype!).

Diagnostic features. Thallus foliicolous, continuous, smooth to minutely farinose, pale greenish to yellowish grey. Apothecia :dnate, rounded to slightly irregular in utline, $0 \cdot 15-0.3 \mathrm{~mm}$ diam.; disc dark brown, convex; margin absent. Excipulum indistinct. Hypothecium dark brown. Paraphyses branched and anastomosing. Asci of the Byssoloma-type. Ascospores 3-septate, narrowly fusiform to almost bacillar, $10-16 \times 2-3 \mu \mathrm{m}$. Conidiomata unknown.

Notes. Santesson (1952) studied the holotype material of Bacidia naevia and found it too scanty to reach any conclusions about its satus and affinities. The epithet remained a nomen dubium until we came across a part of the type collection housed in the Field Museum of Natural History in Chicago (F). Apparently, this and other type material of species described by Vainio came into the herbarium with the incorporation of the $\mathrm{A}$. Herre collection. The isotype material of Bacidia naevia, which also includes an isotype of Bilimbia iloilensis Vain. (=Byssoloma annuum, see Thor et al. 2000), is welldeveloped and represents the same species at was recently described as Fellhanera angustispora (Lücking 1997).

\section{Fellhanera submicrommata (Vězda) Lücking \& Kalb comb. nov..}

Bacidia submicrommata Vězda, Acta Mus. Silesiae, Opava, ser. A, 24: 124 (1975); type: Guinea, Lisowski 1169 (hb. Vězda-holotype!; UPS-isotype!).

\section{(Fig. $1 \mathrm{G} \& \mathrm{H}$ )}

Diagnostic features. Thallus foliicolous, continuous, smooth to minutely farinose, pale bluish grey. Apothecia sessile, rounded, 0.3-0.4 mm diam.; disc blackish brown, flat to slightly convex; margin thin, in old apothecia disappearing, chamois-coloured to pale grey. Excipulum encrusted with colourless crystals; after dissolving the crystals in $\mathrm{KOH}$, its internal parts appear paraplectenchymatous while its external parts are composed of short hyphae with globose cells. Hypothecium dark brown. Paraphyses branched and anastomosing. Asci of the Byssoloma-type. Ascospores 3septate, oblong-ellipsoid, $12-18 \times 4-5 \mu \mathrm{m}$. Conidiomata pycnidia; conidia simple, pear-shaped, c. $3 \times 1 \mu \mathrm{m}$.

Notes. Vězda (1975b) considered this species to be closely related to Bacidia micrommata (Kremp.) R. Sant., differing by its smooth instead of verrucose thallus. We examined a number of specimens referable to $B$. submicrommata and came to the conclusion that there are additional differences, in particular the smaller apothecia with flat to slightly convex disc and thin, evanescent margin, the rather indistinct paraphyses with gelatinous walls, and the pear-shaped conidia. These features point to a relationship with Fellhanera, particularly with the F. stanhopeae-aggregate (Lücking 1997). In fact, Bacidia submicrommata is externally identical with Fellhanera sublecanorina (Nyl.) Vězda, differing only in the crystalline exciple. Both seem to form sister taxa, similar to the pair $F$. stanhopeae (Müll. Arg.) Lücking, Lumbsch \& Vězda and F. lambinonii (Sérus.) Lücking \& Sérus. (Sérusiaux 1996). Fellhanera submicrommata also occurs in the Neotropics, but specimens were previously referred to $F$. sublecanorina by us. Also similar is Byssoloma anomalum 
Kalb \& Vězda, but this species has ochraceous yellow crystals in the exciple, which is composed of hyphae with cylindrical cells.

Additional specimens examined. Guyana: Upper Takutu: Kuyuwini Landing, $40 \mathrm{~km} \mathrm{~S}$ of Aishalton, $2^{\circ} 06^{\prime} \mathrm{N}, 59^{\circ} 15^{\prime} \mathrm{W}, 230 \mathrm{~m}$, foliicolous, 1992, Sipman 36921, 36922 (B).-Peru: San Martin: Tarapoto, $6^{\circ} 30^{\prime} \mathrm{S}, 76^{\circ} 20^{\prime} \mathrm{W}, 350-500 \mathrm{~m}$, foliicolous, iii 1981, Santesson $\mathbb{E}$ Thor s.n. (UPS).

We would like to thank A. Henssen, H. S. MacKee, R. Santesson, F. Schumm, H. Sipman, H. Streimann and A. Vězda for placing valuable collections at our disposal. Two anonymous referees provided valuable corrections on an earlier draft manuscipt. The systematic studies on the Pilocarpaceae, as part of a forthcoming monograph in the Flora Neotropica series, were supported by grants of the Deutsche Forschungsgemeinschaft to RL (Lu 597/1-1; Lu 597/3-1).

\section{REFERENCES}

Ekman, S. (1996) The corticolous and lignicolous species of Bacidia and Bacidina in North America. Opera Botanica 127: 1-148.

Hafellner, J. (1984) Studien in Richtung einer natürlicheren Gliederung der Sammelfamilien Lecanoraceae und Lecideaceae. Nova Hedwigia 79: 241-371.

Kalb, K., Lücking, R. \& Sérusiaux, E. (2000) Studies in Bacidia sensu lato (lichenized Ascomycetes: Lecanorales). I. The genus Bapalmuia Sérus. Mycotaxon 75: 281-309.

Lücking, R. (1997) Additions and corrections to the knowledge of the foliicolous lichen flora of Costa Rica. The genus Fellhanera, with notes on Bacidia pauciseptata. Tropical Bryology 13: 141-173.

Lücking, R. (1999) Foliicolous lichens and their lichenicolous fungi from Ecuador, with a comparison of lowland and montane rain forest. Willdenowia 29: 299-335.

Lücking, R., Farkas, E. É., Sérusiaux, E. \& Sipman, H. J. M. (2000) Checklist of foliicolous lichens and their lichenicolous fungi. Part I. Foliicolous lichens. [http://ivevw. uni-bayreuth.de/departments/ planta2/ass/ robert/lichens/checkfol.html].

Santesson, R. (1952) Foliicolous lichens I. A revision of the taxonrmy of the obligately foliicolous, lichenized fungi. Symbolae Botanicae Upsalienses 12: 1-590.

Sérusiaux, E. (1983) Foliicolous lichens from Zimbabwe. Lichenologist 15: 283-287.

Sérusiaux, E. (1993) New taxa of foliicolous lichens from western Europe and Macaronesia. Nordic fournal of Botany 13: 447-461.

Sérusiaux, E. (1996) Foliicolous lichens from Madeira, with the description of a new genus and two new species and a world-wide key of foliicolous Fellhanera. Lichenologist 28: 197-227.

Thor, G., Lücking, R. \& Matsumoto, T. (2000) The foliicolous lichens of Japan. Symbolae Botanicae Upsalienses 32: 1-72.

Vainio, E. A. (1921) Lichenes insularum Philippinarum, III. Annales Academiae Scienciarum Fennicae, ser. A 15: 1-368.

Vězda, A. (1975a) Foliikole Flechten aus Tanzania (Ost-Afrika). Folia Geobotanica et Phytotaxonomica, Praha 10: 383-432.

Vězda, A. (1975b) Foliicole Flechten aus der Republik Guinea (W.-Afrika). Acta Musei Silesiae, ser. A 24: 117-126.

Vězda, A. (1980) Foliikole Flechten aus Zaïre. I. Die Arten der Sammelgattungen Catillaria und Bacidia. Folia Geobotanica et Phytotaxonomica, Praha 15: 75-94.

Vězda, A. (1986) Neue Gattungen der Familie Lecideaceae s. lat. (Lichenes). Folia Geobotanica et Phytotaxonomica, Praha 21: 199-219.

Vězda, A. (1991) ['1990']) Bacidina genus novum familiae Lecideaceae s. lat. (Ascomycetes lichenisati). Folia Geobotanica et Phytotaxonomica, Praha 25: 431-432.

Vězda, A., Brunnbauer, W. \& Breuß, O. (1997) Foliicole Flechten aus Sri Lanka. Annalen des Naturhistorischen Museums Wien 99B: 737-742.

Zahlbruckner, A. (1921-1940) Catalogus Lichenum Universalis, Vol. I-X. Leipzig: Borntraeger. 